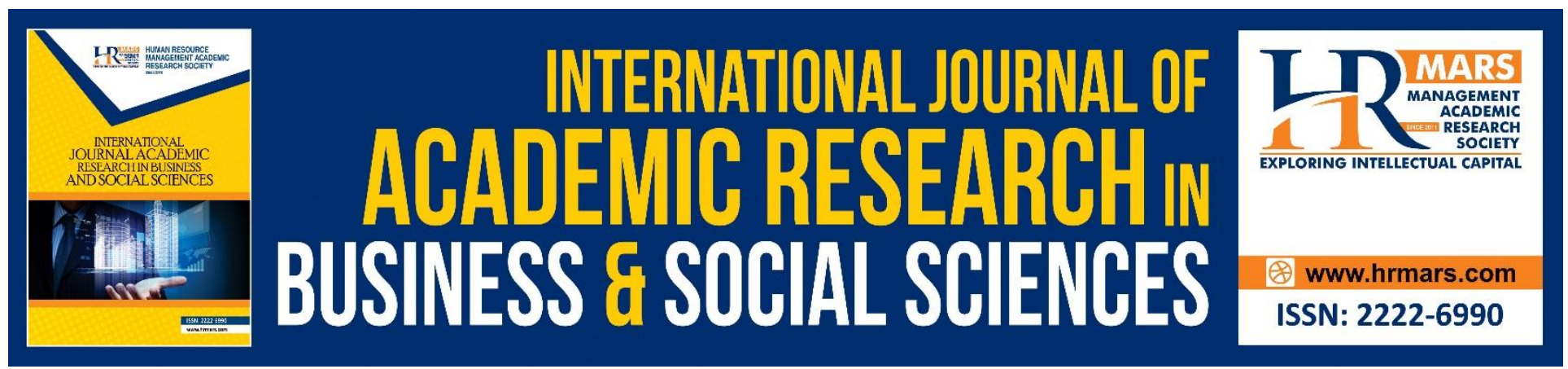

\title{
Problem based Learning: A Pedagogical Approach to Learning in Accounting
}

Adelina Ebun, Amirrul Muhminin Darussamin, Shafawati Farhana Mohd Safihie

To Link this Article: http://dx.doi.org/10.6007/IJARBSS/v8-i10/4775 DOI: 10.6007/IJARBSS/v8-i10/4775

Received: 04 Sept 2018, Revised: 17 Oct 2018, Accepted: 22 Oct 2018

Published Online: 31 October 2018

In-Text Citation:

To Cite this Article:

Copyright: (C) 2018 The Author(s)

Published by Human Resource Management Academic Research Society (www.hrmars.com)

This article is published under the Creative Commons Attribution (CC BY 4.0) license. Anyone may reproduce, distribute, translate and create derivative works of this article (for both commercial and non-commercial purposes), subject to full attribution to the original publication and authors. The full terms of this license may be seen

at: http://creativecommons.org/licences/by/4.0/legalcode

Vol. 8, No. 10, 2018, Pg. $729-738$

Full Terms \& Conditions of access and use can be found at http://hrmars.com/index.php/pages/detail/publication-ethics 


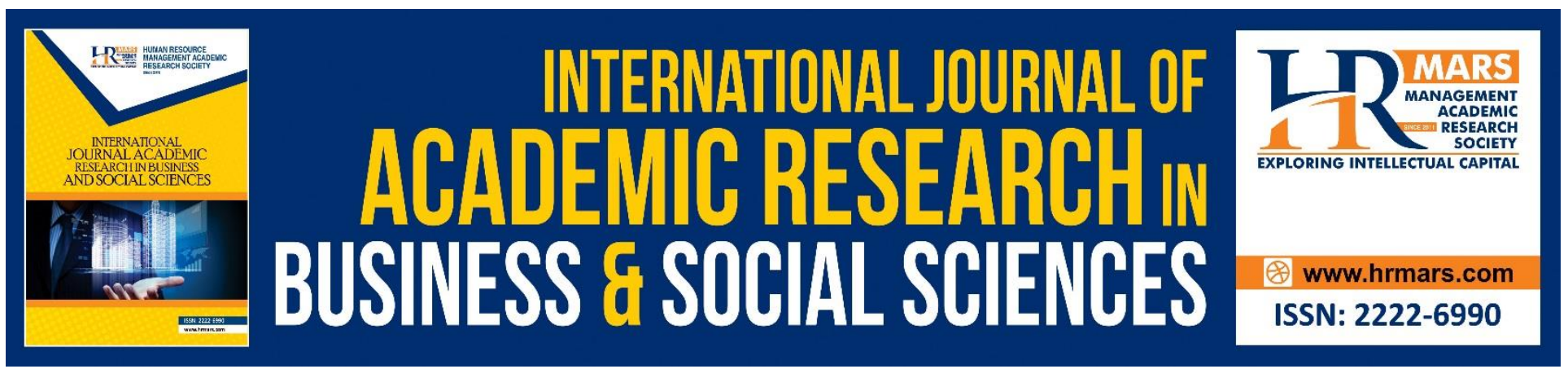

\title{
Problem based Learning: A Pedagogical Approach to Learning in Accounting
}

\section{Adelina Ebun¹, Amirrul Muhminin Darussamin², Shafawati Farhana Mohd Safihie ${ }^{3}$}

123 Faculty of Accountancy, Universiti Teknologi MARA Sabah, Locked Bag 71, 88997 Kota Kinabalu, Sabah

Email: adelinae@sabah.uitm.edu.my, amirrul671@sabah.uitm.my, shafawati697@sabah.uitm.edu.my

\begin{abstract}
Problem-based Learning (PBL) is an instructional method that focuses on problem-solving as a way of acquiring knowledge. PBL had been promoted as an effective learning approach as it promotes critical thinking and encourages students to use self-directed learning skills in the quest for solutions. However, while a number of medical education studies have found a positive impact of PBL on students' academic performance, there is a lack of studies that focus on the usefulness of PBL for students majoring in accountancy studies. This study is motivated to see the extent to which PBL increases students' learning in two financial accounting courses, namely Financial Accounting 1 (FAR110) and Financial Accounting 2 (FAR160) which was conducted at Universiti Teknologi MARA (UiTM) Sabah. In both the FAR110 and FAR160, PBL was used as the teaching and learning methods and also as an assessment tool. In order to achieve the research objective, secondary data comprising students' marks in PBL and their final examination results for both accounting courses were obtained from 177 students. Pearson correlation analysis was performed to examine the relationship between students' marks in the PBL assessments and the final examination results for both courses. The results show a significant, although weak, correlation $(r=0.234)$ between PBL marks and the final examination results for FAR110 but no correlation was found for FAR160. The study suggests that the duration of PBL implementation, student commitments and teaching style adopted by lecturer are factors that may have contributed to the inconsistent results.
\end{abstract}

Keywords: Problem-based Learning, Malaysia, Financial Accounting

\section{Introduction}

Over the past few decades there has been an abundance of studies on teaching and learning. One of the teaching approaches that has gained scholarly interest is the Problem-based Learning (PBL) (Savery and Duffy, 1995). The main difference between PBL and the traditional teaching approach 
INTERNATIONAL JOURNAL OF ACADEMIC RESEARCH IN BUSINESS AND SOCIAL SCIENCES Vol. 8, No. 10, Oct. 2018, E-ISSN: 2222-6990 @ 2018 HRMARS

was the emphasis placed upon student rather than the teacher in the learning process (Colliver, 2000). In PBL, knowledge acquisition was achieved through problem-solving experiences which was implemented within a group setting (Savery and Duffy, 1995). In such situation, students are expected to gain a better understanding of the subject matter since they are directly exposed to a problem. A number of medical education studies such as those conducted by Albanese and Mitchell (1993); Colliver (2000); Norman and Schmidt (2000), have found that PBL is an effective teaching and learning approach. Although PBL was initially introduced in medical education studies, other study disciplines such as engineering (Johnson, 1999; Woods, 1996) and accounting (Johnstone and Biggs, 1998; Milne and McConnell, 2001) have recently integrated PBL into their respective academic curricula.

However, whilst previous studies have shown evidences on the effectivenss of PBL as a teaching and learning approaches, there are relatively limited studies examining how PBL contribute toward better learning particularly among accounting students (Stanley and Marsden, 2012). Furthermore, as most studies on PBL were undertaken within the context of developed countries, the impact of PBL on student learning from the perspective of developing countries remains unclear. Understanding the implementation of PBL from a developing country perspective is vital in order to see whether the introduction of such approach would be fitting to the heavily teacher-centric environment. In most developing countries, teacher plays a dominant role in the learning process. Although this teaching approach is predominantly used in many developing countries, it has a number of deficiencies. First, it reinforces passiveness among students. Secondly, it encourages memorization rather than the understanding of knowledge. Therefore, students who are exposed to this teaching and learning environment tend to be lacking in many important skills such as analytical skill, good judgment, good communication skill, and problem-solving (Porter \& McKibbin 1988). A part from the contextual research gap, a review of past studies also revealed a methodology gap whereby most studies conducted in the past only considered primary data derived from interviews and survey questionnaires to form a view on the effectiveness of PBL (Stanley and Marsden, 2012). In order to have a concrete evaluation of PBL as an effective teaching and learning approach, we argue that one must also consider the impact of PBL on students' examination results.

Therefore, this study attempts to fill the void in the literature by bringing in a case study of PBL implementation in a developing country in order to see whether the new teaching and learning approach would contribute towards better learning among students majoring in accountancy studies. Usinga quantitative research approach, this study examines the implementation of $\mathrm{PBL}$ in the Diploma in Accountancy programme at Universiti Teknologi MARA, Sabah (UiTM Sabah). In doing so, the relationship between students' marks in a PBL assessment and the final examination results was examine in an attempt to see the extent to which PBL contributes towards better academic performance. Specifically in UiTM Sabah, PBL has been adopted as a teaching method and assessment component for two introductory financial accounting courses, namely Financial Accounting 1 (FAR110) and Financial Accounting 2 (FAR160) since 2014. However, no study has been carried out so far to see the impact of PBL on students' academic achievement for both courses. 
INTERNATIONAL JOURNAL OF ACADEMIC RESEARCH IN BUSINESS AND SOCIAL SCIENCES

Vol. 8, No. 10, Oct. 2018, E-ISSN: 2222-6990 @ 2018 HRMARS

This paper is organised as follows. In the next section, a review of relevant literature is provided. This is followed by a brief description of the research method that was used in this study. Next, a discussion of the research findings is presented. The paper ends with concluding remarks.

\section{Literature Review}

In keeping abreast with the ever changing teaching and learning environment, there has been a shift in the approaches to teaching and learning, from the traditional teacher-centred approach to one which encourages students to play an active role in the learning process. This latter teaching approach requires student to be an active learner where critical thinking is crucial. Critical thinking is an important skill that is needed to respond to real-life situations where problems are common. According to Zabit (2010), this skill is just as important as knowledge because it helps a person to adapt and cope with new environmental demands that require a prompt response.

One form of active learning that has been discussed in the academic literature is the Problem-based Learning (PBL) approach (Hoidn and Kärkkäinen, 2014; Stankunas, Czabanowska, Avery, Kalediene, and Babich, 2016). PBL has been promoted as an effective learning approach since it was found to help develop problem solving skills among students (Werth, 2009). Apart from that, the PBL approach to learning was also found to be useful in the development of critical thinking as students are required to find a solution for a complex issues that depict real-world situations using self-directed learning techniques (Hoidn and Kärkkäinen, 2014; Looi and Seyal, 2014; Zabit, 2010). Zabit (2010) asserts that the repetitive processes experienced by students in seeking solution for a problem allow them to acquire knowledge and skills and train them to be more effective in responding to problems. Along the same line of thinking, Grasas and Ramalhinho (2016) suggests that PBL trains students to be more analytical since it provides students with the experience to deal with realistic issues that compels them to dig deep into the problems in order to look for answers.

A number of studies have highlighted the benefits of PBL and the positive impact it has had on students from diverse fields of study. For example, in a study by Stankunas et al. (2016) on students from the health science programme in Lithuania found that PBL not only instigated an intense exchange of ideas and personal experiences among students but it also helped in developing other skills such as public speaking, communication, and logical thinking. This is supported by the study of Looi and Seyal (2014) on students undertaking a programming class in Brunei Darussalam. The findings of their study showed that PBL was an effective learning technique since it advocated collaborative learning in which students could learn from their teammates. Besides that, the study also found that PBL increased learning interest and motivation as well as helped students to develop social skills. In addition, Peng (2010) found that PBL strengthened students' analytical skills, enhanced problem-solving abilities and nurtured self-learning skills in a group of students who took a computer programming course.

However, despite the extensive research carried out on PBL, most of these past studies were conducted in developed countries. There is a general lack of research undertaken to examine PBL as a teaching and learning approach in developing countries such as Malaysia (Zabit, 2010). Furthermore, previous studies on PBL are mostly done within the fields of medical studies, 
engineering, and science and technology (Albanese and Mitchell, 1993; Eldy and Sulaiman, 2013; Looi and Seyal, 2014). The study by Awang and Ramly (2008) is one of the few studies conducted in Malaysia that examined how PBL improved critical thinking skills of engineering students. Another Malaysian case study on PBL was done by Eldy and Sulaiman (2013) who found positive improvement on critical thinking after the implementation of PBL among physics students in Universiti Malaysia Sabah. Besides that, Bamford, Karjalainen, and Jenavs (2012) findings revealed that undergraduate students from an operations management programme were found to have better learning experiences when exposed to problem-based assessments as compared to just using traditional final examinations. These findings were consistent with Downing, Ning, and Shin (2011) study on the effectiveness of PBL from the perspective of undergraduates in Hong Kong University. Downing et al. (2011) found that students who were given exposure to a PBL environment recorded a higher level of course satisfaction compared to those who used the traditional learning method.

The studies discussed above have examined PBL as a teaching and learning approach based on primary data derived from survey questionnaires and interviews. For example Looi (2013) used a survey questionnaire to elicit views of students on their experiences with PBL. The study of Werth (2009) used an in-depth interview to examine the impact of PBL on the development of knowledge and improvement of learning skills particularly in the areas of decision-making, problem-solving, and teamwork. Furthermore, the study conducted by Stankunas et al. (2016) utilised a similar data collection method in which they used an open-ended questionnaire to investigate the feasibility of using PBL as a teaching approach in a health services management training programme. Based on the brief discussion above, it appears that those studies used primary data rather than secondary data to form views on the effectiveness of PBL as a teaching and learning method. This present study aims to complement these studies and contribute to extend literature by investigating the effectiveness of PBL using secondary data.

\section{Research Methodology}

This study used a quantitative approach as the method of data collection and analysis. For the purpose of achieving the research objective, two sets of data were collected and analysed. The first set was the PBL assessment marks which were obtained from three lecturers teaching FAR110 and FAR160. The second data set was the Final Examination results for both course codes which were supplied by the Examination Unit of UiTM Sabah. At the initial stage, the researchers planned to conduct a longitudinal study to observe the relationship between PBL marks and the final examination results across time. However, the incomplete data on PBL only allowed the researchers to examine the relationship between the two variables for the June - September 2016 semester. The final data comprised students' marks for the PBL assessment and the Final Examination results for both FAR110 and FAR160 which were derived from a total of 177 students. All data were considered for further analysis using the statistical software, Statistical Package for the Social Sciences (SPSS).

\section{Discussion of Research Findings}

This section discusses the findings of the analysis carried out in this study. The discussion begins by describing the descriptive statistics of the data considered in this study. The Pearson correlation 
INTERNATIONAL JOURNAL OF ACADEMIC RESEARCH IN BUSINESS AND SOCIAL SCIENCES

Vol. 8, No. 10, Oct. 2018, E-ISSN: 2222-6990 ㄷ 2018 HRMARS

analysis between PBL assessment marks and the final examination results are presented in the last part of this section.

\section{Descriptive Statistics}

Based on Table 1, the average PBL marks for FAR110 (69.62\%) and FAR160 (89.25\%) show that students scored better in FAR160 as compared to FAR110. The minimum and maximum scores for both courses also indicate that students' performance for FAR160 was better than FAR110.

Table 1: Descriptive statistics - PBL

\begin{tabular}{lllll}
\hline Variables & Mean & Std. Dev. & Min. & Max. \\
\hline FAR110 $(n=115)$ & 69.62 & 18.89 & 0 & 98 \\
FAR160 $(n=62)$ & 89.25 & 4.96 & 73 & 97 \\
\hline
\end{tabular}

Contrary to the above findings, the final examination results for both courses as provided in Table 2, show that FAR110 (66.09\%) outperformed FAR160 (64.85\%), albeit at a marginal score range. In terms of the minimum and maximum score range, students from both groups scored between " 0 " and "100". The results show that although students' performance for FAR110 was better than FAR160, the overall performance was more or less the same.

Table 2: Descriptive statistics - final examination

\begin{tabular}{lllll}
\hline Variables & Mean & Std. Dev. & Min. & Max. \\
\hline FAR110 $(n=115)$ & 66.09 & 24.29 & 0 & 100 \\
FAR160 $(n=62)$ & 64.85 & 23.91 & 0 & 100 \\
\hline
\end{tabular}

In order to have a clearer views of students' performance in PBL and in the final examination, students' marks for both FAR110 and FAR160 were grouped based on four levels of performance namely, 'Excellent', 'Good', 'Moderate', and 'Weak' as in Tables 3 and 4. As indicated in Table 3, FAR160 recorded a high percentage of students in the 'Excellent' category (94\%) in PBL. Notably, the PBL marks obtained by students undertaking FAR160 were within the range of 65 to 100 . In the case of FAR110, students in the 'Excellent' (39\%) and 'Good' (21\%) categories were more than those in the 'Moderate' (29\%) and 'Weak' (11\%) categories. This indicates that students performed well in PBL for both FAR160 and FAR110.

Table 3: Level of performance - PBL

\begin{tabular}{llllll}
\hline \multirow{2}{*}{$\begin{array}{l}\text { Level of } \\
\text { performance }\end{array}$} & \multicolumn{3}{l}{ FAR110 } & \multicolumn{2}{l}{ FAR160 } \\
\cline { 2 - 6 } & $\begin{array}{l}\text { Score } \\
\text { range }\end{array}$ & Frequency & Percentage & Frequency & $\begin{array}{l}\text { Percentage } \\
\%\end{array}$ \\
\hline Excellent & $80-100$ & 45 & 39 & 58 & 94 \\
Good & $65-79$ & 24 & 21 & 4 & 6 \\
Moderate & $50-64$ & 33 & 29 & 0 & 0 \\
Weak & $0-49$ & 13 & 11 & 0 & 0 \\
\hline Total & & 115 & 100 & 62 & 100 \\
\hline
\end{tabular}


Table 4 shows the number of students in the four levels of performance based on their final examination results. It appears that $16 \%$ and $35 \%$ of students who took FAR160 and FAR110 were in the 'Excellent' categories respectively. However, when the percentages of 'Excellent' and 'Good' categories were combined, FAR160 (63\%) outperformed FAR110 (55\%). Therefore, the conclusion drawn from this observation indicates that although more students scored higher marks (65 and above) for FAR160, students actually performed better in FAR110 as most of them scored the highest marks (80-100) in FAR110.

Table 4: Level of performance - final examination

\begin{tabular}{llllll}
\hline \multirow{2}{*}{ Level of } & \multicolumn{3}{l}{ FAR110 } & \multicolumn{3}{l}{ FAR160 } \\
\cline { 2 - 6 } performance & Score & Frequency & Percentage & Frequency & Percentage \\
& range & $f$ & $\%$ & $f$ & $\%$ \\
\hline Excellent & $80-100$ & 40 & 35 & 10 & 16 \\
Good & $65-79$ & 23 & 20 & 29 & 47 \\
Moderate & $50-64$ & 28 & 24 & 8 & 13 \\
Weak & $0-49$ & 24 & 21 & 15 & 24 \\
\hline Total & & 115 & 100 & 62 & 100 \\
\hline
\end{tabular}

1.1 Results of the Pearson correlation analysis

To further support the view that PBL is an effective teaching and learning approach, an investigation of the relationship between students' marks in PBL and their final examination results of the two financial accounting courses were carried out. In doing so, the Pearson correlation analysis was performed to establish a relationship between the two variables in an attempt to see whether PBL impacted the final examination results. Results of the Pearson correlation analysis as presented in Table 5 reveal that there is a significant relationship between PBL marks and the final examination results for FAR110 ( $r=0.234)$. However, the $r$ value implies a weak relationship between the two variables. On the other hand, there is no correlation between PBL marks and the final examination results for FAR160 ( $r=0.133)$.

Table 5: Pearson correlation - FAR110 \& FAR160

\begin{tabular}{llrlr}
\hline Variable & FAR110 & \multicolumn{3}{l}{ FAR160 } \\
\hline & PBL & Final Exam & PBL & Final Exam \\
PBL & 1 & 1 & \\
Final Exam & 0.234* & 1 & 0.133 & 1 \\
$*$ & Correlation is significant at the & 0.05 level & (2-tailed). \\
\hline
\end{tabular}

\section{Concluding Remarks}

This study aims to see the effectiveness of PBL in enhancing students' academic performance using a case study of PBL implementation involving two accounting courses offered under the Diploma in Accountancy programme at Universiti Teknologi MARA, Sabah (UiTM Sabah). This is done by examining the relationship between students' marks in PBL and their final examination results. 
Findings of this study revealed that there is a significant relationship between PBL marks and the final examination results for FAR110. However, no relationship was found between PBL marks and the final examination results for FAR160. It is argued that the inconsistent results between PBL and the final examination results for the two courses do not necessarily indicate that PBL, by itself, is an ineffective teaching or learning approach. There are other reasons that may have contributed to the inconsistent results.

First, PBL may be effective in enhancing student learning only when it is implemented over a longer period of time but not within a short time period. In the case of FAR160, the PBL assessment was done in the final week before the semester ended. Since the topic taught using PBL was the last topic in the lesson plan, students were more likely given a limited time to complete the PBL assignment. In such a situation, students could have resorted to copying answers from other groups for the sake of getting marks. Therefore, it can be conjectured that the learning experience that is expected to benefit students may not have been fully achieved. This was reflected by high marks in the PBL assignment but low marks in the final examination.

Secondly, PBL may be effective only when students assume their responsibility and play an active role as team members. It can be argued that students who fully contributed in completing the PBL assignment were the ones who benefited the most. Students who only joined the group but did not do much may score high marks in the PBL assessment but may fail to perform in the final examination.

Lastly, the implementation process of PBL for both courses may be different depending on the teaching style adopted by the lecturers in charge. This may be the case especially in terms of grading of students' works. For the Diploma in Accountancy programme, the final examination answer scripts are evaluated based on a centralised marking system. Under this system, students' answer scripts are evaluated by another lecturer who is not involved in teaching a particular group. In such circumstances, there is a possibility for differences in the grading of students' work depending on leniency/strictness of lecturers/evaluators. It is argued that leniency/strictness of a particular lecturer does have an impact on students' marks in PBL and the final examination.

Whilst the above explanations may be true, they are only assumptions. Therefore, future studies may be carried out to test their validity.

\section{Acknowledgement}

The authors greatly appreciate the cooperation and assistance of the Examination Unit, UiTM Sabah especially from Mr Muhd Zahimi bin Janai and Ms Norhayati Othman in providing the necessary data used in this study. 
INTERNATIONAL JOURNAL OF ACADEMIC RESEARCH IN BUSINESS AND SOCIAL SCIENCES

Vol. 8, No. 10, Oct. 2018, E-ISSN: 2222-6990 @ 2018 HRMARS

\section{Corresponding Author}

${ }^{1}$ Adelina Ebun

Faculty of Accountancy, Universiti Teknologi MARA Sabah, Locked Bag 71, 88997 Kota Kinabalu, Sabah

Email: adelinae@sabah.uitm.edu.my

\section{References}

Albanese, M. A., \& Mitchell, S. (1993). Problem-based learning: a review of literature on its outcomes and implementation issues. . Academic Medicine, 68(1), 52-81.

Awang, H., \& Ramly, I. (2008). Creative thinking skill approach through problem-based learning: Pedagogy and practice in the engineering classroom. International Journal of Human and Social Sciences, 3(1), 18-23.

Bamford, D., Karjalainen, K., \& Jenavs, E. (2012). An evaluation of problem-based assessment in teaching operations management. International Journal of Operations \& Production Management, 32(12), 1493-1514. doi: 10.1108/01443571211284214

Colliver, J. A. (2000). Effectiveness of problem-based learning curricula: research and theory. Academic Medicine 75(3), 259-266.

Downing, K., Ning, F., \& Shin, K. (2011). Impact of problem-based learning on student experience and metacognitive development. Multicultural Education \& Technology Journal, 5(1), 55-69. doi: $10.1108 / 17504971111121928$

Eldy, E. F., \& Sulaiman, F. (2013). The Capability of Integrated Problem-Based Learning in Improving Students" Level of Creative-Critical Thinking. International Journal of e-Education, e-Business, e-Management and e-Learning, 3(4), 347-350. doi: http://dx.doi.org/10.7763/IJEEEE.2013.V3.257

Grasas, A., \& Ramalhinho, H. (2016). Teaching distribution planning: a problem-based learning approach. The International Journal of Logistics Management, 27(2), 377-394. doi: 10.1108/IJLM-05-2014-0075

Hoidn, S., \& Kärkkäinen, K. (2014). Promoting skills for innovation in higher education: A literature review on the effectiveness of problem-based learning and of teaching behaviours: OECD Publishing.

Johnson, P. A. (1999). Problem-based, cooperative learning in the engineering classroom. Journal of Professional Issues in Engineering Education and Practice, 125(1), 8-11.

Johnstone, K. M., \& Biggs, S. F. (1998). Problem-based learning: Introduction, analysis, and accounting curricula implications. Journal of Accounting Education, 16(3), 407-427.

Looi, H. C. (2013). A Problem Based Learning Approach to Teaching a Computer Programming Language. Paper presented at the International Proceedings of Economics Development and Research, Singapore.

Looi, H. C., \& Seyal, A. H. (2014). Problem-based Learning: An analysis of its application to the teaching of programming. Paper presented at the International Proceedings of Economics Development and Research, Singapore.

Milne, M. J., \& McConnell, P. J. (2001). Problem-based learning: a pedagogy for using case material in accounting education. Accounting Education, 10(1), 61-82. 
INTERNATIONAL JOURNAL OF ACADEMIC RESEARCH IN BUSINESS AND SOCIAL SCIENCES

Vol. 8, No. 10, Oct. 2018, E-ISSN: 2222-6990 ㄷ 2018 HRMARS

Norman, G. R., \& Schmidt, H. G. (2000). Effectiveness of problem-based learning curricula: Theory, practice and paper darts. Medical Education, 34(9), 721-728. doi: 10.1046/j.13652923.2000.00749.

Peng, W. (2010). Practice and experience in the application of problem-based learning in computer programming course Paper presented at the 2010 International Conference on Educational and Information Technology (ICEIT)

Porter, L. W., \& McKibbin, L. E. (1988). Management Education and Development: Drift or Thrust into the 21st Century? : ERIC.

Savery, J. R., \& Duffy, T. M. (1995). Problem based learning: An instructional model and its constructivist framework Educational technology (Vol. 35, pp. 31-38).

Stankunas, M., Czabanowska, K., Avery, M., Kalediene, R., \& Babich, S. M. (2016). The implementation of problem-based learning in health service management training programs: Experience from Lithuanian University of Health Sciences. Leadership in Health Services, 29(4), 392-401. doi: 10.1108/LHS-04-2015-0010

Stanley, T., \& Marsden, S. (2012). Problem-based learning: Does accounting education need it? Journal of Accounting Education, 30, 267-289.

Werth, E. P. (2009). Student perception of learning through a problem-based learning exercise: an exploratory study. Policing: An International Journal of Police Strategies \& Management, 32(1), 21-37. doi: 10.1108/13639510910937094

Woods, D. R. (1996). Problem-based learning for large classes in chemical engineering. New Directions for Teaching and Learning, 68, 91-99. doi: 10.1002/tl.37219966813

Zabit, M. N. M. (2010). Problem-Based Learning On Students' Critical Thinking Skills In Teaching Business Education In Malaysia: A Literature Review. American Journal of Business Education, 3(6), 19-32. 